\title{
Application of GIS, precision agriculture and unplugging cultivation in plant breeding of Karcag
}

\author{
Róbert Czimbalmos - Éva Mónika Fazekas - Eszter Murányi \\ Research Institute of Karcag, Institutes for Agricultural Research and Educational Farm, University of Debrecen \\ rczimb@agr.unideb.hu
}

SUMMARY

\begin{abstract}
In the last two decades, the prevailing ecological conditions and climate change have caused negative effects. Therefore, a paradigm shift is needed in the field growing of plants. The latest inventions, digital technologies, precision cultivation are not enough, the mentality of the farmers is more important. For this reason, not only big financial sacrifices, but adequate receptivity are needed on behalf of farmers. Adequate skills and continuous self-education are necessary. The yield of plant growing farms is determined by ecological conditions to a $40 \%$ extent, genetic background of the seed has a 30\% share and the applied agricultural technology has a proportion of 30\%. In different agroecological conditions, bred varieties of plants have bigger tolerance to unfavorable factors of the regions and significant yield stability. Farmers, who buy and sow seeds, can only contribute to the genetic potential of the seeds with cultivation technology. Plant breeding provides stable genetic background and good quality seeds. Breeding activity - choosing variety proposants, breeding them, selection work, classical breeding process for 8-10 years - must create new landraces, which can produce balance, high yield and have good quality parameters in extreme ecological conditions, yearly excursion and have higher tolerance to unfavorable factors of the region giving significant production stability for farmers. In Karcag GIS technology, precision cultivation elements and soil-friendly agrotechnical methods have been introduced which largely support the aims of breeding and can also provide optimal cultivation conditions in extreme years. Because of the specificity of breeding the main aim is not only to increase yield but to provide harmonic growing for bred materials, to decrease the number and the cost of cultivation and to be punctual. In this study, applied new methods and technologies are introduced.
\end{abstract}

Keywords: plant breeding, climate change, GIS methods, precision farming, unplugging mulching system

\section{INTRODUCTION}

The agriculture of the world is before an enormous challenge, catastrophyc effects of climate change are known, the number of areas, which can be introduced into cultivation, are terminated, the population of the world may reach 9 billions by 2050. According to the evaluation of the World Meteorological Organization (WMO), warming tendency also continued in longterm in 2018: the average global surface temperature is the 4. highest since the beginning of the extended meteorological measures. The warmest twenty years have been registrated in the past 22 years and the last four years were the warmest globally. According to Szellő (2019) in Hungary 2018 has been the warmest since 1901. ENSZ reported that every year 24 billion tons of topsoil get lost all over the world because of the intensive agriculture. On the half of Hungary's fields a large and fast degradation process has already started (Nagy, 2014). Water-, warmth- and air-viability of the soil decline because of the harmful compaction, which affects the productivity of bred plants (Nagy, 2018). In our country, the number of the state-acknowledged wheat genotypes is plenty, so this wide range makes it difficult to choose the adequacy for a growing area and a technological level. A good or bad choice of a genotype can initially determine the effectiveness and profitability of the plant. It is important to consider the field conditions and the level of the applied agrotechnique. The genotype must be adapted to the ecological conditions (weather, soil) and the agrotechnical applications (forecrop, fertilisation, plant protection, harvest). Because of the significant number of wheat varieties or hybrids, each genotype differently reacts to the agrotechnical applications, they have different optimal. To reach the best genetic production potential of the variety or the hybrid, it is important to apply corresponding variety- or hybrid-specific agrotechnique to needs of the plant (Pepó, 2017). According to Bedő and Láng (2004) in our country plant production, plant breeding and economic policy are needed together to close the crop shears. Bigger yield with less input material can only be produced by intensive programmes in agricultural research to improve water- and fertilizer-application, to increase production yield, to develop biotic and abiotic stressresistance and to produce more, good quality seeds. The main aim of plant breeding is to create new varieties, which have bigger fertility, disease-resistance and provide safety biological basis for plant production (Braun et al., 1997). Breeding of landraces suited to a region/district largely contributes to the environmental sustainability, has the smallest environmental load in given agroecological, soil and agrotechnical conditions and varieties suited into the land can be produced economically and with large stability. Only varieties with large plasticity, abiotic- and biotic-stress resistance can adapt to the extremities caused by climate change, so breeding such landraces is a big challenge for our present and a long-term aim for breeders (Czimbalmos, 2016). Especially, the Hungarian winter wheat production must have basically two steps. The first step is to apply our former knowledge, to complete optimal species- and varietyspecific technologies carefully (Pepó, 2018). For these aims, plant breeding needs continuous reformation and 
innovation (Polgár, 2018). Besides classical plant breeding activities, significance of supportive new cultivation techniques and other innovative technologies - GIS and precision agriculture - has become more valuable recently. Besides parrying harmful effects of climate changes, broadening irrigation facilities, precision ideas, IT techniques, sensors and drones will gain bigger and bigger roles (Szellö, 2018). Drones have been used for plant protection in China for ten years (Zováthi, 2019). The health stage of the plants on the basis of chlorophyll content can be concluded with analysing raw satellite images (NDVI index ${ }^{1}$, Red Edge Index ${ }^{2}$ ). If in the investigated plant stand there are bigger stains the modified vegetation index, SAVI (Soil-Adjusted Vegetation Index) must be applied. From satellite images after suitable trasformation processses a very punctual estimation can be given for the expected yield (Harangi, 2017). To preserve and increase the efficiency of breeding, the breeders must carefully do cultivation and plant care. In the case of cereals, the main requirement is to maintain soil conditions for contributing the safety production (Birkás, 2002). In the Hungarian climate and soil conditions, the unplugging mulching system has a proved advantage (Üveges, 2018). Application of soil-moisture preservation (Berényi et al., 2018) and druoghtdecreasing new cultivation methods have a very big importance in agriculture (Czimbalmos, 2017). In the experiments of breeding wheat varieties in Karcag comparing classical and unplugged cultivation - we concluded that in the growing season with extreme drought or in polders wheat cultivated with unplugged method has higher yield than cultivated with traditional method (Czimbalmos, 2014). Nutrition supply, plant protection and taking soil samples are very important activities: their punctuality and efficiency can be enhanced with the application of site-specific agriculture. In 2018 in Hungary on only $1 \%$ of the fields (50 000 hectare) precision farming was applied. According to the feedback of the power- and workmachine traders and macro-economical impact assessments, this new agricultural system will explodingly spread in the future. Most experts in the agriculture agree that precision farming is the future for plant production (Takács, 2017), and its values are undoubted (Popp, 2017). At present, this technology is in the booming phase (Kemény et al., 2017). Its wider spread has two main inhibitors, high purchase price of neccessary investments and the lack of adequate professional knowledge (Takács, 2015); the lack of united ruling system in connection with the technology, if the farmer introduces this, he realizes the expected advantages (Molnár et al., 2018).

\section{MATERIALS AND METHODS}

The experimental area is in Nagykunság, the most extreme land of the Great Hungarian Plain. It is very $\mathrm{dry}^{3}$, the average amount of the precipitation is between 400-550 mm. Breeding of winter wheat, winter barley, triticale and alternative plants, variety creation, production of phylum mixture and high growth ability seeds (prebasic, basic seed) take place on the better quality fields of the Research Institution of Karcag, indicated with B1-, B2-, I2 and H2 (Figure 1). The area needs of nursery is 6-8 hectars, because of the isolation distance sorghum species need plus areas every year. The soil of the nursery is solonets meadow chernozem. In this land with extreme soil and climate conditions winter cereals and alternative plants have no real alternatives, the local bred varieties can adapt and use the agroecological potential of this land better.

The first aims of the breeding activity are the excellent adaptability and the favorable components indicators (high protein content, favorable amino-acid composition), untimeliness and excellent drought- and frost-resistance. The most important method of our breeding is to select species based on pedigree selection. Parents derive from different sources: traditional varieties, landraces, bred plants phylums (acknowledged varieties or former variety nominee which did not state acknowledgment), other genetical sources. The aim of our breeding is to create varieties which are untimely, seedful, resistant to the unfavorable soil- and climate conditions and have good stem strength. We created phylums with excellent raw materials which are suitable for the demand of the farmers (Czimbalmos, 2019). Breeding of the total variety sortiment of Karcag (14 species 38 varieties) is completed by traditional methods, with moderate areaand human resource- capacity, so it is important to use the good quality agrotechnique and the tight resources as effectively as possible. This is helped by the special agrotechnique of seeds production (Bedö, 2004), the institute's own equipments of GIS method and precision farming besides equipments of breeding and accredited laboratory (plant and soil examinations). The GIS applications and the RTK (Real-Time Kinamatic Network) controlled power machines of the precision farming consist of official (ArcGIS 9.2, WayQuest, Digiterra Explorer v4, GoogleMaps) for GIS softwares and field computers (Thales MobileMapper, Trimble RTK), very punctual GPS tools and power- and working-machines of the unplugged cultivation system of the Institute (Czimbalmos et al., 2017).

\footnotetext{
${ }^{1}$ Index (NDVI - Normalised Difference Vegetation Index) by Rouse et al. (1973) is used for characterising biophysical state of the plant covering.

${ }^{2}$ Red Edge Index describes the shape and the position of reflectancy curves.

${ }^{3}$ Drought index by Pálfai (PAI) values are between maximum 9-10.
} 
During cultivation the two, most important parameters of machine operation are the traction for trailing working machines and fuel-consumption can be detected, data bases are used in the economical analysis. The upper parameters can be edited on own map-overlays which contain routes of cultivation and the overlays of the own edited plots' poligons and their attributive databases which change in every growing season. GIS data are processed by GIS softwares, we also use dedicated softwares and spreadsheets to process cultivation databases. Map database contains the digital forms of the traditional cadastral map sites, digital orthophoto-maps and the own-edited thematic maps of every year. This initial database with the bought maps and their attributive databases provides to make actual maps and reports.

\section{Figure 1: The nursery in 2018/2019}

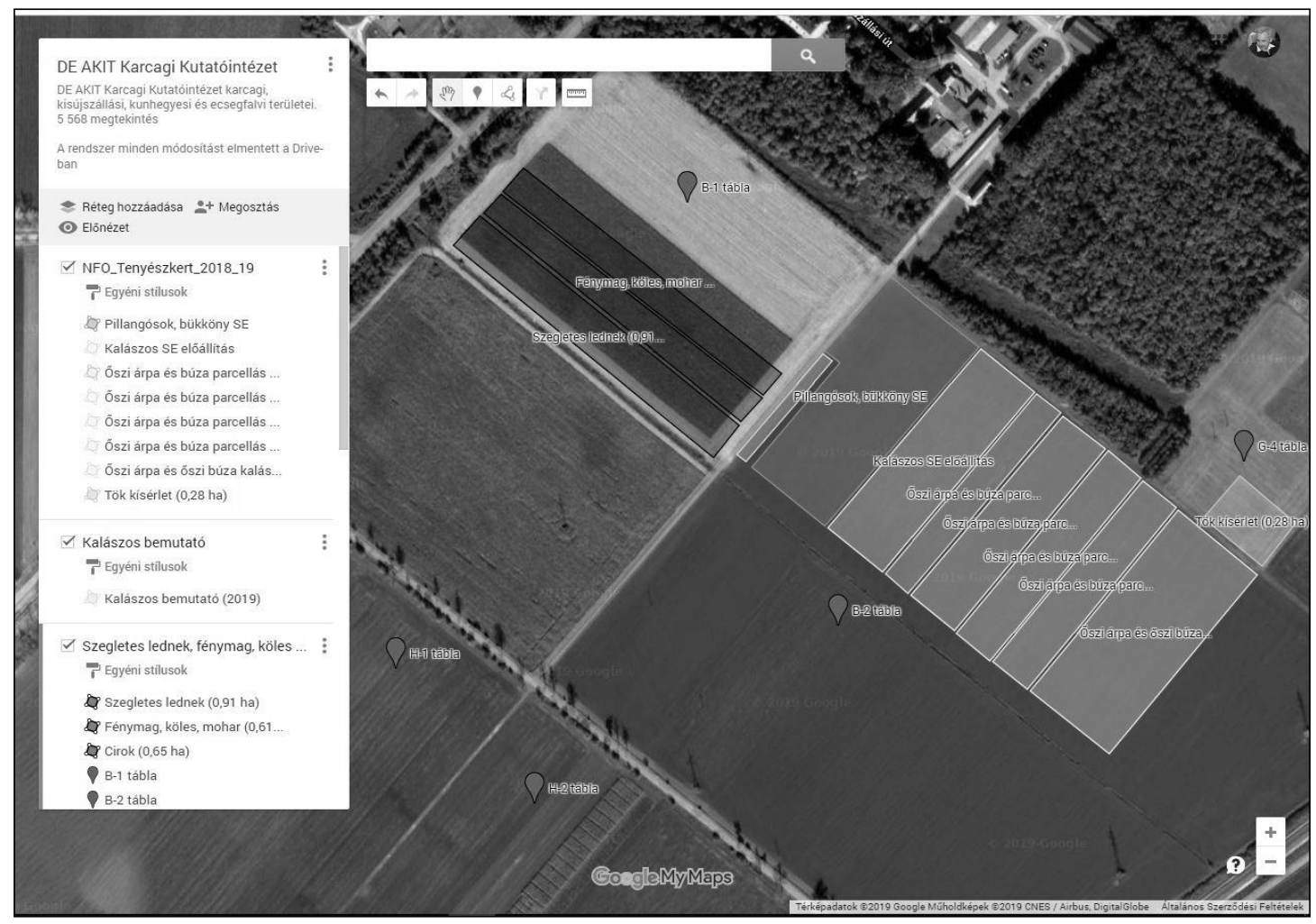

(Source: own edition on GoogleMaps)

\section{RESULTS AND DISCUSSION}

In the recent decades of plant production paradigm shift - the treaty of cultivation technology shift, digitalisation and precision cultivation - was not unwaited for the research in the Institute, such researches started before the turn of the millenium. The precision farming adaptively applies innovation results of GIS. The results of the research have been applied at factory level, so appeared in breeding: very punctual taking soil samples (Differencial GPS) and examinations, differentiated nutrition supply, patchy, different deep, periodic deep cultivation within one plot, sowing, plant protection and plant care with the help of RTK, unplugged cultivation technology, recording fuel consumption of power machines. With this complex technology fuel-, fertilizer-, seeds- and prowork- utilisation can be decreased. The comparison of traditional and unplugged cultivation system in our Institute proves this statement (Table 1).

Breeding activity starts with professional choosing the nursery, and preparation its soil. It is important to keep isolation distance and provide the adequate previous crop. For design of the nursery field, local knowledge, field measurements, measuring and indicating plots with traditional methods are tiring and time-consuming tasks. 
The value of Total Traction Power Demand (TPD) and fuel consumption in the two basic tools of the two cultivation methods (Measurement time: 06.11.2017, type of tractor: JD 8285R)

\begin{tabular}{|c|c|c|c|c|c|}
\hline Plough & TPD & TPD max. & Fuel consumption & Cultivated area & Fuel consumption \\
\hline (H-1, Corn stubble) & $(\mathrm{kN})$ & $(\mathrm{kN})$ & (litre) & (hectare) & $\left(1 \mathrm{ha}^{-1}\right)$ \\
\hline First measurement & $111,418.4$ & 98.42 & \multirow{8}{*}{31.6} & 0.10 & \multirow{9}{*}{44.6} \\
\hline Second measurement & $120,584.6$ & 106.5 & & 0.10 & \\
\hline Third measurement & $123,148.8$ & 107.7 & & 0.10 & \\
\hline Fourth measurement & $102,610.5$ & 105.8 & & 0.10 & \\
\hline Mean & $118,383.9$ & 104.2 & & & \\
\hline First measurement & $121,912.5$ & 99.60 & & 0.10 & \\
\hline Second measurement & $110,235.2$ & 96.14 & & 0.10 & \\
\hline Third measurement & $127,074.1$ & 110.03 & & 0.10 & \\
\hline \multirow[t]{2}{*}{ Mean } & $119,740.6$ & 101.9 & 4.51 & 0.71 & \\
\hline & \multicolumn{5}{|c|}{ IH Plow's working width in meter: $2 \mathrm{~m}$} \\
\hline $\begin{array}{c}\text { Disk Ripper (2) } \\
\text { (H-2 Corn stubble) }\end{array}$ & TPD & TPD max. & Fuel consumption & Cultivated area & Fuel Consumption \\
\hline First measurement & $41,918.6$ & 53.24 & \multirow{9}{*}{30.4} & 0.20 & \multirow{10}{*}{18.8} \\
\hline Second measurement & $63,752.5$ & 74.37 & & 0.20 & \\
\hline Third measurement & $67,918.1$ & 77.28 & & 0.20 & \\
\hline Fourth measurement & $58,449.5$ & 61.54 & & 0.20 & \\
\hline Mean & $57,863.1$ & 66.61 & & & \\
\hline First measurement & $63,604.9$ & 74.46 & & 0.20 & \\
\hline Second measurement & $65,057.4$ & 73.88 & & 0.20 & \\
\hline Third measurement & & & & 0.20 & \\
\hline Fourth measurement & $60,559.6$ & 71.32 & & 0.20 & \\
\hline \multirow[t]{2}{*}{ Mean } & $64,331.2$ & 74.20 & 3.8 & 1.61 & \\
\hline & & & & \multicolumn{2}{|c|}{ Disk-ripper's working width in meter: $4.2 \mathrm{~m}$} \\
\hline
\end{tabular}

Figure 2: Flooded areas on B-1 and B-2 fields in 2006

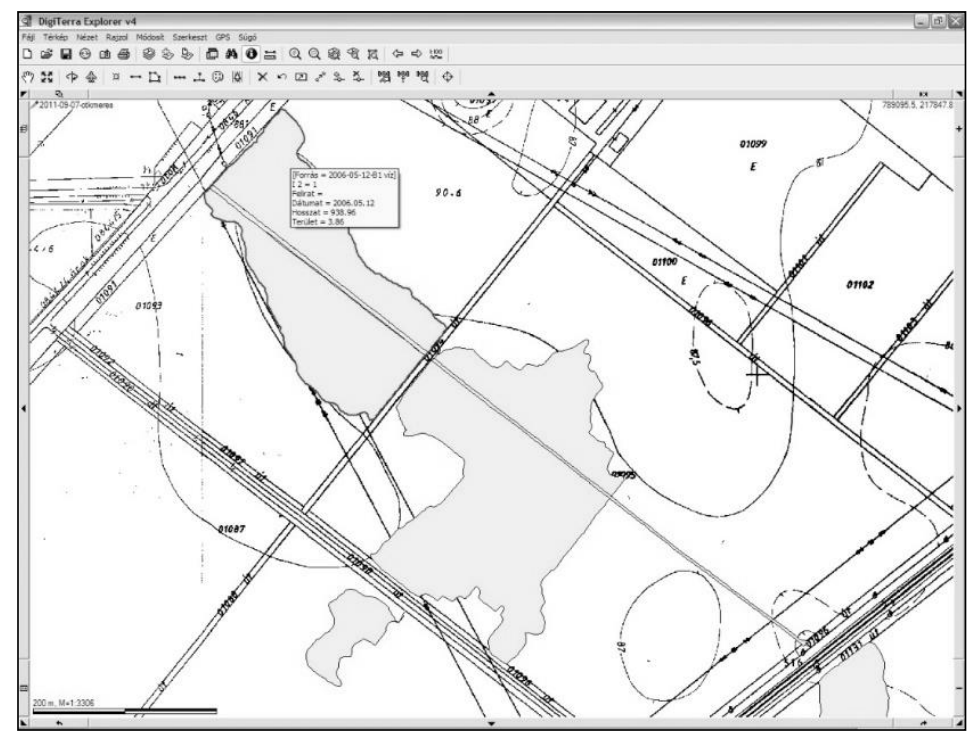

(Source: own database)

These activities are speeded and specified by the very punctual GPS equipment, which be can used for the following: measuring regular and irregular shaped poligons depending on field conditions, fixing corner points, measuring field barriers and point-like establishments, control length- and area-measurements, assessing exposed areas by vis maior events (Figure 2), designing and fixing soil sample taking points, to do taking samples, making nutrition-supply and other thematic maps, identification definited points, yearly area measuring tasks. After the fast and punctual field measurement, the sowing plan of the nursery is made in the office, based on the data measured on the field. Firstly, the total sowing plan of the nursery is made on 
the spreadsheet (Table 2). This is made for every species and variety, taking field barriers into consideration with planning borders and cultivation roads. The map basis is given by the cadastral map overlays, on these own-edited map sites can be found. On these there is the actual right size nursery, which is the new thematic map for the given year. In this study, the map and attributive database of 2018/2019 growing season is introduced. The thematic map after office design is raw material for researchers and assistants, who measure plots on the field. After the neccessary soil preparations, winter cereals are sowed with special small-plotted self-propelled HEGE and trailed
Wintersteiger seeding machines. In the spring phenophase corner points and poligons of the plots are fixed and edited by field GPS again to get the definitive, thematic map database of the nursery (Figure 3), where plots, turning areas, remained areas by the end of the plots and the spring sowing plots, poligons of the new nursery with the neccessary information (name, size, treatments, photos and video etc.). Autumn and spring soil cultivation, soil preparation need large care in as little steps as possible and good quality according to the protocol of the unplugged cultivation system of the Institute.

Winter wheat experiments on B-1 field (Detail of the sowing plan)

\begin{tabular}{|c|c|c|c|c|c|c|c|c|c|c|c|c|c|c|c|c|c|c|}
\hline \multirow{7}{*}{$\begin{array}{l}5 \\
4 \\
3\end{array}$} & \multicolumn{17}{|c|}{ Winter wheat plant density experiment } & \multirow{7}{*}{ 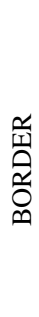 } \\
\hline & \multirow{6}{*}{$\begin{array}{l}\frac{a}{1} \\
\frac{1}{2} \\
\frac{0}{0}\end{array}$} & $\mathrm{~T} 31$ & $\mathrm{~T} 41$ & T34 & $\mathrm{T} 51$ & $\mathrm{~T} 24$ & $\mathrm{~T} 14$ & T54 & $\mathrm{T} 44$ & $\mathrm{~T} 21$ & T53 & $\mathrm{T} 52$ & $\mathrm{~T} 43$ & $\mathrm{~T} 24$ & $\mathrm{~T} 13$ & $\mathrm{~T} 22$ & $\mathrm{~T} 11$ & \\
\hline & & $\mathrm{T} 12$ & $\mathrm{~T} 32$ & $\mathrm{~T} 22$ & $\mathrm{~T} 23$ & $\mathrm{~T} 34$ & T52 & $\mathrm{T} 13$ & $\mathrm{~T} 32$ & T54 & T51 & $\mathrm{T} 11$ & $\mathrm{~T} 42$ & $\mathrm{~T} 12$ & $\mathrm{~T} 33$ & $\mathrm{~T} 44$ & $\mathrm{~T} 41$ & \\
\hline & & $\mathrm{T} 23$ & $\mathrm{~T} 21$ & $\mathrm{~T} 44$ & $\mathrm{~T} 42$ & $\mathrm{~T} 53$ & $\mathrm{~T} 11$ & $\mathrm{~T} 33$ & $\mathrm{~T} 43$ & $\mathrm{~T} 34$ & $\mathrm{~T} 14$ & T54 & $\mathrm{T} 24$ & $\mathrm{~T} 31$ & $\mathrm{~T} 21$ & $\mathrm{~T} 32$ & $\mathrm{~T} 13$ & \\
\hline & & $\mathrm{T} 14$ & $\mathrm{~T} 33$ & $\mathrm{~T} 31$ & $\mathrm{~T} 43$ & $\mathrm{~T} 51$ & $\mathrm{~T} 41$ & $\mathrm{~T} 53$ & $\mathrm{~T} 12$ & $\mathrm{~T} 42$ & $\mathrm{~T} 52$ & $\mathrm{~T} 22$ & $\mathrm{~T} 23$ & $\mathrm{~T} 54$ & $\mathrm{~T} 53$ & $\mathrm{~T} 52$ & $\mathrm{~T} 51$ & \\
\hline & & $\mathrm{T} 11$ & $\mathrm{~T} 12$ & $\mathrm{~T} 13$ & $\mathrm{~T} 14$ & $\mathrm{~T} 21$ & $\mathrm{~T} 22$ & $\mathrm{~T} 23$ & $\mathrm{~T} 24$ & $\mathrm{~T} 31$ & $\mathrm{~T} 32$ & $\mathrm{~T} 33$ & $\mathrm{~T} 34$ & $\mathrm{~T} 41$ & $\mathrm{~T} 42$ & $\mathrm{~T} 43$ & $\mathrm{~T} 44$ & \\
\hline & & 16 & 15 & 14 & 13 & 12 & 11 & 10 & 9 & 8 & 7 & 6 & 5 & 4 & 3 & 2 & 1 & \\
\hline & \multicolumn{18}{|c|}{ Winter wheat variety experiment } \\
\hline 6 & \multirow{7}{*}{ 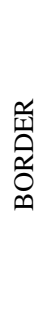 } & SZ4 & KG8 & SZ5 & KG7 & SZ6 & $\mathrm{SZ2}$ & SZ8 & SZ7 & KG3 & KG6 & SZ10 & $\mathrm{X}$ & KG4 & KG2 & SZ1 & KG1 & \multirow{7}{*}{ 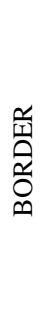 } \\
\hline 5 & & KG2 & SZ2 & SZ1 & SZ8 & SZ3 & SZ5 & KG4 & KG5 & SZ4 & $\mathrm{X}$ & KG7 & SZ12 & SZ11 & KG9 & SZ9 & KG5 & \\
\hline 4 & & KG9 & KG6 & SZ7 & $\mathrm{SZ12}$ & KG8 & KG9 & KG10 & SZ11 & SZ6 & SZ9 & SZ8 & KG1 & $X$ & SZ3 & KG3 & SZ4 & \\
\hline 3 & & KG4 & KG5 & $\mathrm{SZ3}$ & SZ9 & SZ12 & KG1 & SZ10 & KG3 & SZ1 & SZ7 & SZ5 & SZ6 & KG6 & $X$ & KG10 & KG8 & \\
\hline 2 & & KG7 & KG10 & SZ10 & $\mathrm{X}$ & SZ11 & $X$ & SZ2 & $X$ & $X$ & KG2 & SZ12 & SZ11 & SZ10 & SZ9 & SZ8 & SZ7 & \\
\hline 1 & & KG1 & KG2 & KG3 & KG4 & KG5 & KG6 & KG7 & KG8 & KG9 & KG10 & SZ1 & SZ2 & $\mathrm{SZ3}$ & $\mathrm{SZ4}$ & SZ5 & SZ6 & \\
\hline & & 16 & 15 & 14 & 13 & 12 & 11 & 10 & 9 & 8 & 7 & 6 & 5 & 4 & 3 & 2 & 1 & \\
\hline
\end{tabular}

(Source: own database)

The main aim is to form the damp, wet, adequately compacted seed-bed. All machine works on the experimental field are registered electronically. Actions by power machines (soil preparation, cultivation, sowing, using chemicals and plant care) can be followed up, during cultivation consuming data can be downloaded through the Vehicle Control System of the Institute, based on GPS.

The summary of actions in the growing season of 2018-2019 is showed by Table 3, based on the worksheet of the machines.

Figure 3: Cultivation garden overlay in autumn 2018 and its punctual version in April 2019

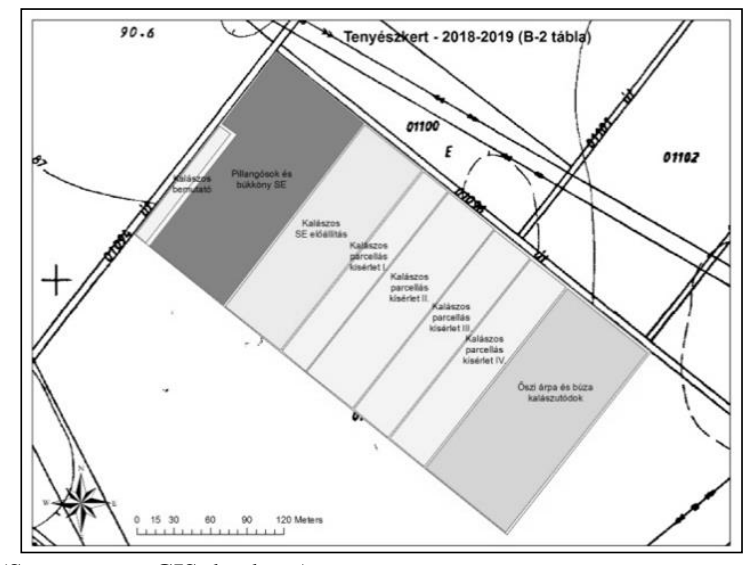

(Source: own GIS database)

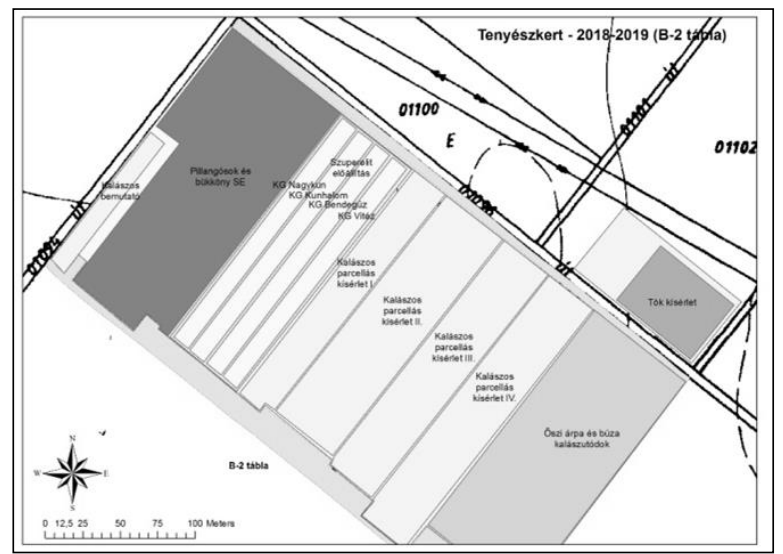


Soil cultivation and care works of B-1-2 fields, part of worksheet (2018-2019)

\begin{tabular}{|c|c|c|c|c|c|c|c|c|c|c|c|c|c|}
\hline 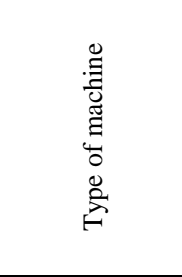 & $\stackrel{\dddot{\Xi}}{\pi}$ & 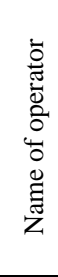 & 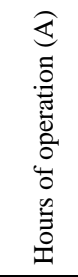 & 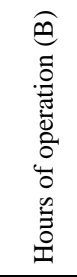 & $\begin{array}{l}\mathbb{1} \\
\qquad\end{array}$ & 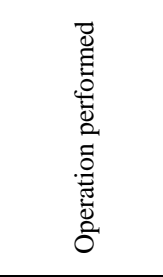 & 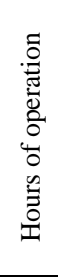 & 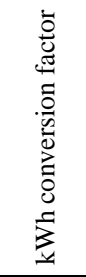 & 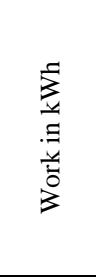 & 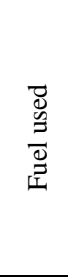 & $\frac{\vec{\Xi}}{\underline{\underline{a}}}$ & 巳્气 & 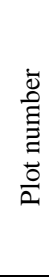 \\
\hline JD 6620 & 01.10 .2018 & $* * *$ & 9501 & 9506 & 5 & Multitilling & 5 & 52.38 & 261.9 & 64.4 & Stubble & 9 & B2 \\
\hline JD 6620 & 10.10.2018 & $* * *$ & 9520 & 9522 & 2 & $\begin{array}{l}\text { HEWA, } \\
\text { smoother }\end{array}$ & 2 & 34.92 & 69.84 & 35.1 & Stubble & 9 & B2 \\
\hline $\begin{array}{l}\text { HEGE } \\
\text { seeding- } \\
\text { machine }\end{array}$ & 25.10 .2018 & $* * *$ & 883 & 903 & 20 & Sowing & 12 & 8.64 & 103.68 & 46.7 & Cereals & 5.7 & B2 \\
\hline JD 6620 & 26.02.2019 & $* * *$ & 9622 & 9626 & 4 & Harrowing & 4.1 & 52.38 & 214.76 & 96.6 & Stubble & 1.3 & B1 \\
\hline JD 6620 & 26.02.2019 & $* * *$ & & & & Harrowing & & 52.38 & & & Vetch & 1.1 & B1 \\
\hline JD 6620 & 26.02.2019. & & & & & Harrowing & & 52.38 & & & Canary grass & 0.2 & B1 \\
\hline MTZ-82 & 28.02.2019 & $* * *$ & 2341 & 2344 & 3 & Harrowing & 3.3 & 19.8 & 65.34 & 29.4 & Stubble & 1.3 & B1 \\
\hline MTZ-82 & 28.02.2019 & $* * *$ & & & & Harrowing & & 19.8 & & & Vetch & 1.1 & B1 \\
\hline MTZ-82 & 28.02.2019 & & & & & Harrowing & & 19.8 & & & Canary grass & 0.2 & B1 \\
\hline IHFarmall & 26.02.2019 & $* * *$ & 3060 & 3060 & 0 & Fertilizing & 0.4 & 16.1 & 6.44 & 2.9 & Barley & 0.4 & B2 \\
\hline IHFarmall & 26.02.2019. & $* * *$ & & & & Fertilizing & & 16.1 & & & Wheat & 0.9 & B2 \\
\hline $\begin{array}{l}\text { HEGE seeding- } \\
\text { machine }\end{array}$ & 05.03.2019 & $* * *$ & 903 & 904 & 1 & Sowing & 1 & 8.64 & 8.64 & 3.9 & Vetch & 0.1 & B2 \\
\hline $\begin{array}{l}\text { HEGE seeding- } \\
\text { machine }\end{array}$ & 07.03.2019 & $* * *$ & 904 & 905 & 1 & Sowing & 1 & 8.64 & 8.64 & 3.9 & Canary grass & 0.2 & B1 \\
\hline IH Farmall & 06.03.2019 & $* * *$ & 3083 & 3083 & 0 & Chemicals & 0.3 & 16.1 & 4.83 & 2.2 & Vetch & 1.1 & B1 \\
\hline IH Farmall & 06.03.2019 & $* * *$ & & & & Chemicals & & 16.1 & & & Vetch & 0.1 & B2 \\
\hline JD-8200 & 04.03.2019. & $* * *$ & 4492 & 4493 & 1 & Sowing & 1 & 57.24 & 57.24 & 25.8 & Vetch & 1.1 & B1 \\
\hline MTZ-82 & 04.03.2019. & $* * *$ & 2356 & 2357 & 1 & Rolling & 0.9 & 19.8 & 17.82 & 8.0 & Vetch & 1.1 & B1 \\
\hline MTZ-82 & 04.03.2019 & $* * *$ & 2357 & 2359 & 1 & Schemer & 1.3 & 29.7 & 38.61 & 17.4 & Stubble & 0.9 & B1 \\
\hline Pasquali & 05.03.2019. & $* * *$ & 10 & 10,6 & 1 & Ring rolling & 0.6 & 6.84 & 4.10 & 1.8 & Vetch & 0.1 & B2 \\
\hline Pasquali & 07.03.2019 & $* * *$ & 10 & 10,7 & 1 & Ring rolling & 0.7 & 6.84 & 4.78 & 2.2 & Canary grass & 0.2 & B1 \\
\hline Pasquali & 27.03.2019 & $* * *$ & 9 & 15,5 & 7 & Cutter shoot & 6.5 & 10.26 & 66.69 & 30.0 & Barley & 0.4 & B2 \\
\hline Pasquali & 27.03.2019. & & & & & Cutter shoot & & 10.26 & & & Barley & 1.6 & B2 \\
\hline Pasquali & 27.03.2019 & $* * *$ & & & & Cutter shoot & & 10.26 & & & Wheat & 0.9 & B2 \\
\hline Pasquali & 27.03.2019. & & & & & Cutter shoot & & 10.26 & & & Wheat & 3.7 & B2 \\
\hline
\end{tabular}

(Source: own database)

On 9 hectars of the nursery, soil preparation with multitiller was done on 1st October 2018, which consumed 64.41 diesel oil, the following cultivation was on 10th October (HEWA rolling then smoothing), which consumed 311 fuel. Plant protection treatments are done by precision technique. Power-machine with discontinuous hung sprayer enables punctual application, is guided by RTK, is equipped with a robotic pilot, follows spray roads punctually, minimizes treading, increases the effectiveness of the application and optimizes turnings. In 2019 two preventive treatments were done on a 3-hectar field (protection against crop bleaching and fungus disease on the plots of cereals and legumes).

Data of the vehicle control system, which is the base of the precision farming, provides basic data for controlling work-sheets of the power-machines, and for filling the electronical field register. In the tracking system the routes gone by power- and work-machines appear on the own-edited overlays about agricultural fields. The report of the software contains the momentary and total fuel consuming, the driven road, and the area of the cultivated field. Figure 4 shows the travel log: data of multitiller done on 1st October 2018 on the field B-1 can be read together (fuel consumption 64.4 1, driven road $28.6 \mathrm{~km}$, waiting, inactive time 35 minutes etc.), the area of the experimental field driven by power-machine during cultivation $(9$ hectars poligon), and the momentary consumption- and speeddiagrams.

Bred varieties by the Institute and the available field area predestinated the formation of the structure of Research Institute Karcag. From the results of the new methods on the basis of agroeconomical analysis of the Institute, the main income source is clear: growing own bred varieties, production and selling certified seeds with high productivity (prebasic, basic seed, I. grade), which represents higher values and provides extra income. Construction of the production structure serves this aim, naturally in the crop structure there are also other industrial plants (sunflower, rape, maize). 
On the field of the Institute, the economical analysis of the technological plan of producing basic seed winter wheat seed shows, that the costs of seed-production are lower per hectar with own seeds, precision farming, combinate with unplugged cultivation, than with traditional cultivation.

Figure 4: Travel log of multitiller in autumn 2018 with track routes and diagrams

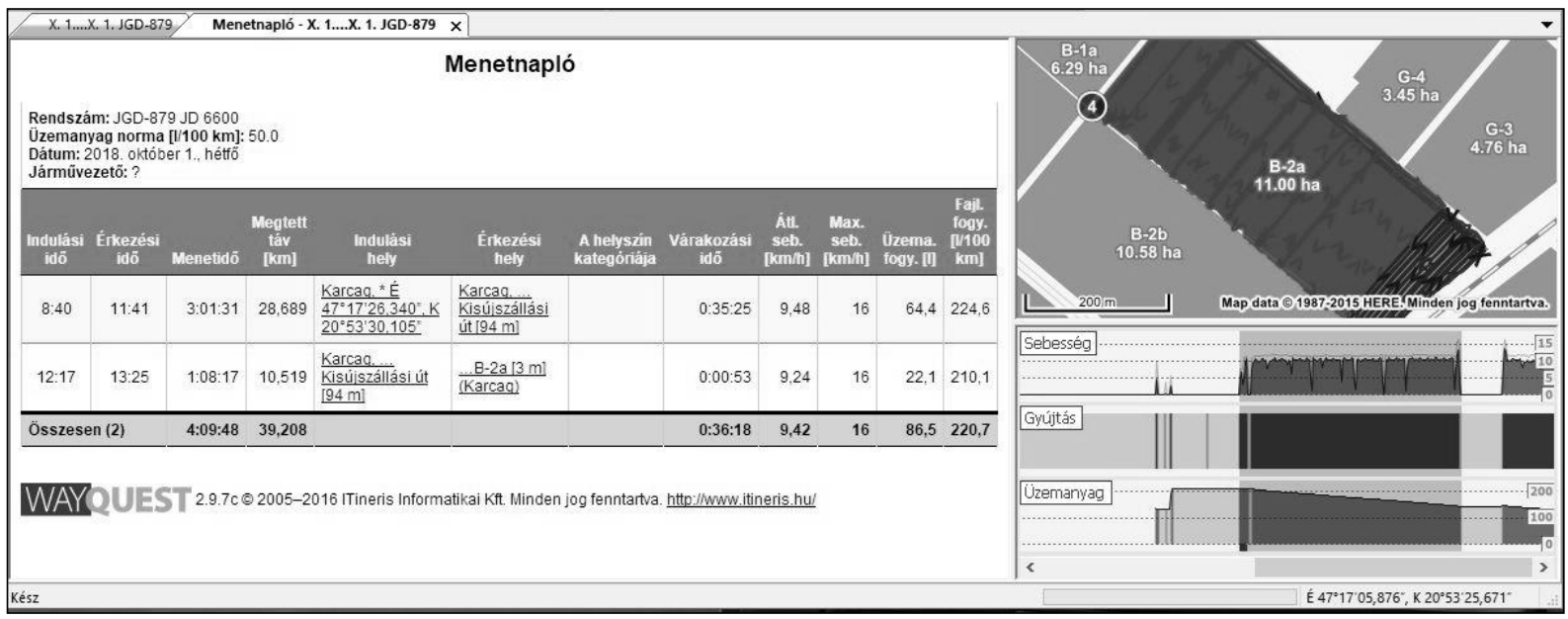

(Source: own database)

All costs of unplugged cultivation are lower $25 \%$ than of traditional cultivation. Adding soil preparations of 2016 to agrotechnical actions, it is clear that the unplugged cultivation combined with the precision farming has advantages opposite the traditional cultivation because deep plowing, multi-step plowing tilth, baling and transporting by-product fall off. According to the consuming and cultivation database of the winter wheat seed production we can say that within costs of cultivation with decreased steps $35-45 \%$ fuel save can be reached. The income-cost analysis showed that $40 \%$ of auxiliary costs and 5-10\% of material costs (costs of seeds and pesticides) can be reduced. In total, the achieved $20-25 \%$ saving is significant because the plants in crop rotation have reached yield growth for more years (Czimbalmos et al., 2017).

\section{CONCLUSIONS}

Ecological conditions of the last three decades have largely changed, because of the negative effects of the climate change the significance of region specific plant breeding has been appreciated. The landraces have better tolerance to the extreme agroecological conditions. In Research Institute of Karcag, on Plantbreeding and Variety-maintenance Department variety-producing and -maintenance, phylum mixture production, seeds with high productivity (prebasic and basic seed) production are largely supplied by the complex treaty of the applied GIS methods, the precision farming and the soilsaver, moisture preservational, unplugged cultivation, which are considered as the part of the paradigm change in plant production. With the introduction of these, classical plantbreeding activities can be done in optimal conditions, in better quality, with less humanwork and with lower costs. Conclusions during the classical plantbreeding activities supported by these methods:

- From the results of the growing seasons in the last five years it can be determined that in spite of the different precipitation and temperature conditions of the years quantitative and qualitative features of our own-bred varieties show small differences, so we managed to meet the breeding goals.

- Crop safety can be further raised, production cost can be decreased and sustainable agriculture can be continued by good quality seeds and with the application of elements of the most modern, unplugged, soil moisture preserving and precision farming system.

\section{REFERENCES}

Bedő, Z. (2004): A vetőmag születése; a vetőmagtermesztés elmélete és gyakorlata. Agroinform Kiadó és Nyomda Kft. Budapest. 537, 143-191.

Bedő, Z.-Láng L. (2015): A jövő növényeinek szerepe a növénytermesztés fenntartható fejlődésében. Gazdálkodás. 59. 4: 305-314.

Berényi, J.-Tánczné Óvári, Cs. (2018): Csökkenthető az aszálykár? AgroNapló. 22. 17-18.
Birkás, M. (2002): Az őszi kalászosok talajmüvelésének kritikus pontjai. Agrofórum. 13. 9: 7-15.

Braun, H. J.-Altay, F.-Kronstad, W. E.-Beniwal, S. P. S.-McNab, A. (1997): Breeding priorities of winter wheat programs. In: Wheat: Prospects for Global Improvement. Developments in Plant Breeding. 6. Springer. Dordrecht. (megtekintve 2019. március 20-án: https://link.springer.com/chapter/10.1007/97894-011-4896-2_72\#citeas) 
Czimbalmos, Á. (2016): Az évjárat hatása az őszi búza egyes értékmérő tulajdonságaira a Nagykunságban. Doktori értekezés. Debreceni Egyetem Kerpely Kálmán Doktori Iskola, Debrecen. 166. p. Megtekintve 2019.03.01 https://dea.lib.unideb.hu/dea/handle/2437/221973

Czimbalmos, Á.-Czimbalmos, R. (2014): Vetésváltás, talajművelés és tápanyagellátás összefüggései az öszi búza termesztésben. Értékálló Aranykorona. XIV. 8: 15-19.

Czimbalmos, R. (2017): Helyspecifikus gazdálkodás alkalmazásának tapasztalatai a forgatás nélküli müvelésben Karcagon. Az elmélet és a gyakorlat találkozása a térinformatikában. Debrecen Egyetemi Kiadó. Debrecen. 73-80.

Czimbalmos, R.-Kovács, Gy.-Tuba, G. (2017): Alacsony termelési költségeket és magas hozamokat biztosító új talajvédő müvelési rendszer alkalmazásának tapasztalatai Karcagon. Magyar vidék - Perspektívák, megoldások a XX. században. I. Vidékfejlesztési Konferencia. Szarvas. 54-59.

Czimbalmos, Á.-Czimbalmos, R.-Murányi, E.-Fazekas, É. M. (2019): A karcagi öszi árpa nemesítés eredményeiről, valamint a legújabb fajta (KG Nagykun) bemutatása. In: Növénynemesítés a 21. század elején: kihívások és válaszok: XXV. Növénynemesítési Tudományos Nap. 2019. Budapest. Magyarország. Magyar Tudományos Akadémia Agrártudományok Osztályának Növénynemesítési Tudományos Bizottsága. 262-265.

Harangi, A. (2017): Termésbecslés lehetőségének becslése LANDSAT 8 műholdfelvételek alapján. DE MÉK Víz- és környezetgazdálkodási Intézet. Diplomamunka. Informatikus és szakigazgatási agrármérnök szak. 53.

Kemény, G.-Takácsné Gy., K.-Gaál, M.-Keményné H., Zs. (2017) A precíziós szántóföldi növénytermesztési technológiára való átállás becsült makrogazdasági hatásai, különös tekintettel a beruházási költségekre és megtérülésére. Gazdálkodás. 61. 3: 223-234.

Kemény, G.-Lámfalusi, I.-Molnár, A. (2017): A precíziós szántóföldi növénytermesztés összehasonlító vizsgálata. Agrárgazdasági Kutató Intézet. Budapest, 170. (megtekintve 2019.03.22:

http://repo.aki.gov.hu/2488/1/2017_K_03_Precizios_konyv_we b_pass.pdf)
Molnár, A.-Kiss, A.-Illés, I.-Lámfalusi, I. (2018): A precíziós és a konvencionális szántóföldi növénytermesztés összehasonlító vizsgálata. Gazdálkodás. 62. 2: 123-134.

Nagy, J. (2014): A földmüveléstan oktatásának és kutatásának története a Debreceni Egyetemen. Debreceni Szemle. 103. (megtekintve 2019. április 24.: https://dea.lib.unideb.hu/dea/bitstream/handle/2437/93038/43_2 014_05_25.PDF?sequence=1)

Nagy, Z. (2018): Átalakulóban a növénytermesztés. Mezőhír. XXII. 2: $58-62$.

Pepó, P. (2017): Fókuszban a genotípus - fajta/hibridspecifikus agrotechnika alapelvei a búzánál és a repcénél. Agrofórum - A Növénytermesztők és Növényvédők Havilapja. 28: 8-11.

Pepó, P. (2018): Búzatermesztésünk feladatai. Magyar Mezőgazdaság: A Magyar Mezőgazdaság Művelődési Társaság Lapja. 73: 26-27.

Polgár, G. (2018): Új értékek teremtése növénynemesítési innovációval. Vetőmag. XXV. 1:2-3.

Popp, J.-Hollósi, D.-Fazakas, P.-Oláh, J. (2017): A versenyképes mezőgazdaság, a földár és a föld jövedelemtermelő képességének összefüggései. Gazdálkodás, 61. 6: 491-504.

Szellő, G. (2018): Izgalmas 25 év, kihívásokkal teli jövő. Vetőmag. XXV. 4: 6-7.

Szellő, G. (2019): A klímaváltozással a mezőgazdaságnak is számolnia kell. Vetőmag. XXVI. 1: 6-8.

Takácsné Gy., K. (2015): Mezőgazdasági innováció és fenntartható fejlődés. LVII. Tudományos Georgikon Napok Tudományos Konferencia kiadványa. 395-407 (megtekintve 2018. december.11-én: http://napok.georgikon.hu/en/papers/papers2012/doc_view/232-lvii-georgikon-napok-kivonatkoetet )

Üveges, Zs. (2018): Talajnedvesség-megőrző és aszálykárt mérséklő módszerek a mezőgazdaságban. Mezőgazdasági Technika. 59: 18-20.

Zováthi, D. (2019): A drónoknak nem csak térkép e táj. Magyar Hírlap. 52. 94: 11. 